\title{
Pemanfaatan E-KTP Sebagai Alat Bantu Sistem Kehadiran Pegawai dalam Penanggulangan Penyebaran Covid-19
}

\author{
Abednego Dwi Septiadi, Luky Sufra Alfarizi
}

Universitas Amikom Purwokerto, Indonesia

\section{Article Info}

\section{Article history:}

Received, 3 September 2020

Revised, 9 September 2020

Accepted, 20 September 2020

\section{Kata Kunci:}

RFID

Sistem Informasi Kehadiran

Protototipe

E-KTP

Penyebaran

\begin{abstract}
ABSTRAK
Dimasa pandemik Covid-19, yang perlu dihindari adalah kontak secara langung maupun terhadap siapapun baik dalam lingkungan rumah maupun pekerjaan. Sistem informasi kehadiran yang masih menggunakan pembaca sidik jari cukup rentan dalam penyebaran virus ini, sehingga perlu dikembangkan sebuah alat untuk menghindari kontak fasilitas yang dipakai dan disentuh oleh orang banyak. Kartu Tanda Penduduk Elektronik (E-KTP) yang dimiliki oleh penduduk Indonesia di dalamnya terdapat chip yang dapat dibaca dengan RFID (Radio Frequency Identification) dapat digunakan sebagai pemicu atau pelatuk ID seorang karyawan, sehingga seseorang dapat meminimalisir untuk bersentuhan dengan objek atau fasilitas umum yang dapat mengantarkan atau menyebarkan virus. Penelitian ini menggunakan metoode Prototyping yang mempunyai karakter perulangan, dari fase mendengarkan konsumen sampai dengan evaluasi, hal itu mendukung terciptanya sistem informasi kehadiran yang dapat mengatasi permasalahan diatas. Penelitian ini akan berdampak dalam pencegahan penyebaran Covid19 yang dialami sekarang ini, sesuai dengan anjuran pemerintah untuk dapat meminimalisir kontak dengan orang lain baik kontak langsung maupun tidak langsung berupa penggunaan sarana prasarana secara bersama-sama.
\end{abstract}

Keywords:

RFID

Attendance Information Sistem

Prototype

E-KTP

Spread

\begin{abstract}
During the Covid-19 pandemic, what needs to be avoided is direct contact with anyone, both in the home and work environment. The presence information sistem that still uses a fingerprint reader is quite vulnerable in the spread of this virus, so it is necessary to develop a tool to avoid contact facilities that are used and touched by many people. E-KTP owned by Indonesian residents contains a chip that can be read with RFID (Radio Frequency Identification) which can be used as a trigger or trigger for an employee's ID, so that a person can minimize contact with objects or public facilities that can transmit or spread viruses. This study uses a prototyping method that has a repetitive character, from listening to consumers to evaluation, it supports the creation of an attendance information sistem that can solve the above problems. This research will have an impact in preventing the spread of Covid-19 that is currently being experienced, in accordance with government recommendations to minimize contact with other people, both direct and indirect contact, in the form of using infrastructure together.
\end{abstract}

\section{Penulis Korespondensi:}

Abednego Dwi Septiadi,

Program Studi Sistem Informasi,

Universitas Amikom Purwokerto.

Email: abednego@amikompurwokerto.ac.id 


\section{PENDAHULUAN}

Virus Corona merupakan pandemi yang mudah menyebar secara contagious. Karena itu, banyak pemimpin yang menghimbau warganya untuk melakukan social distancing dan isolasi untuk mencegah penularan virus penyakit ini [1]. Imbas dari masa pandemic Covid-19 adalah mengurangi atau meminimalisir bersentuhan dengan orang lain, yang berarti tidak membenarkan kontak secara langsung melalui jabat tangan, bersentuhan tangan maupun kontak tidak langsung berupa penggunaan sarana dan prasarana secara bersamasama dalam waktu yang dekat. Pengurangan kontak akan berpengaruh terhadap pencegahan penyebaran virus Corona yang sedang kita alami bersama, tidak terkecuali dalam perkantoran dimana akhir-akhir ini muncul klaster (cluster) baru dari area perkantoran karena masih cukup banyak penerapan pemindai sidik jari dalam proses pencatatan kehadiran disebuah perusahaan ataupun kantor. Penyebaran virus harus segera ditangani, karena jika tidak ditangani dengan maksimal maka semakin banyak tingkat pengidap virus ini yang akan selalu meningkat hingga suatu saat nanti akan mencapai titik stabil.[2]

Pemerintah sebagai penyelenggara dan pengatur Negara, harus menjamin rakyatnya untuk tetap selamat dengan langkah-langkah nyata dalam mengendalikan bahkan menanggulangi Covid-19 ini, masyarakat juga harus cermat dan pintar dalam bertindak maupun mambuat inovasi dalam pengendalian dampak pandemic ini. Pemerintah menganjurkan kepada siapapun yang batuk dan yang menderita penyakit influenza untuk menggunakan masker, tujuannya untuk membatasi percikan droplet dari yang bersangkutan [2]. Pemerintahan harus menjalankan protokol kesehatan dengan benar dan baik, salah satunya menghindari kontak antar karyawan dilingkungan desa yaitu dengan menerapkan sistem kehadiran minim kontak dengan fasilitas umum yang digunakan yaitu sistem kehadiran dengan pembacaan sidik jari.

Salah satu prasarana yang telah dimiliki hampir sebagian besar masyarakat Indonesia adalah E-KTP yang didalamnya terdapat chip yang dapat dibaca dengan alat pembaca Radio Frequency Identification. E-KTP yang sudah dimiliki oleh masyarakat saat ini belum banyak digunakan khususnya dalam administrasi yang mengharuskan identifikasi identitas, E-KTP yang mengandung chip ini merupakan kartu pintar atau smartcard berbasis microcontroller dengan besaran memory 8 kilobytes yang dapat menyimpan data diri seseorang. Hal ini menjadi kontra produktif dengan banyaknya biaya yang dipakai untuk membuat E-KTP ini [3]]. Pengelolaan pendaftaran penduduk merupakan tanggung jawab pemerintah kabupaten atau kota, dimana dalam pelaksanaannya diawali dari desa atau kelurahan selaku ujung tombak pendaftaran penduduk, hingga setiap warga terdaftar secara administrasi sebagai warga negara Indonesia dan sesuai dengan Undang-Undang Nomor 23 Tahun 2006 tentang Administrasi Kependudukan [4]].

Tag RFID terbuat dari microchip dengan dasar bahan dari silikon yang mempunyai kemampuan fungsi identifikasi sederhana yang disatukan dalam satu disain. Kemampuan tag RFID untuk dibaca dan ditulis (read/write) serta kemudian disimpan pada sarana penyimpanan mendukung proses enkripsi dan kontrol akses yang dilakukan. Sedangkan reader RFID adalah perangkat untuk membaca tag RFID. Kartu cerdas ini memiliki nomor seri berbeda satu dengan lainnya atau unik yang ditanamkan pada IC memori yang digunakan untuk menyimpan informasi yang dibutuhkan []].

Untuk menekan laju penularan Covid-19, pemerintah Indonesia mengimbau menjaga jarak fisik (physical distancing), kerja dari rumah, belajar di rumah, hingga beribadah di rumah. Berdasarkan imbauan tersebut sejumlah pemerintah daerah mengambil kebijakan dengan memberlakukan aturan belajar di rumah bagi siswa sekolah []. Pemanfaatan E-KTP dalam sistem informasi kehadiran pada penelitian ini akan membaca chip dengan RFID reader untuk mengekstrak data-data yang dibutuhkan sebagai pemicu atau trigger dari sistem kehadiran ini. Karyawan atau orang yang akan melakukan sistem presensi tidak perlu melakukan kontak langsung dengan mesin pembaca untuk meminimalisir penyebaran virus yang tidak diharapkan. Permasalahan berikutnya adalah para pemangku kepentingan atas data kehadiran ini juga harus mengaksesnya dari tempat kerja atau kantornya, maka diperlukan sebuat sistem kehadiran yang data kehadirannya dapat diambil dimanapun dan kapanpun, sehingga diperlukan sebuah website untuk penyajian data tersebut.

Untuk mengembangkan sistem informasi kehadiran ini memerlukan metode pengembangan sistem informasi sehingga dapat memperjelas kerangka kerja yang akan dipakai, karena sistem yang akan dibangun adalah sistem yang cukup kompleks dan membutuhkan konsep model bekerja (working model) maka tepat jika menggunakan metode pengembangan sistem prototyping. Metode ini akan menjamin keakuratan dan kecepatan dalam pembangunan sebuah sistem informasi yang berorientasi pada kasus atau masalah konsumen. Metode prototype memberikan gambaran melalui rencana dan rancangan aplikasi yang kemudian akan dievalusi oleh user yang selanjutnya akn dijadikan acuan untuk membuat aplikasi yang dijadikan output dari sebuah penelitian []]. 
Penelitian ini akan mengambil lokasi penelitian di Kantor Desa Maos Kidul, Kecamatan Maos, Kabupaten Cilacap, sehingga penelitian ini akan menghasilkan pilot project sistem informasi kehadiran dengan E-KTP sebagai trigger data kehadiran yang dapat diimplementasikan atau diterapkan dikantor pemerintahan lainnya, baik tingkat desa, kecamatan maupun kabupaten. Tujuan dari penelitian ini akan membangun sebuah sistem informasi kehadiran pegawai yang mampu mendukung kebijakan pemerintah dalam physical distancing dan meminimalisir penggunaan sarana dan prasarana secara bersama-sama. Sistem ini akan membaca E-KTP yang dimiliki oleh masyarakat sehingga tidak memerlukan prasarana untuk dapat diimplementasikan dalam dunia nyata. Manfaat yang lain adalah berperan aktif dalam pencegahan penyebaran Virus Corona atau yang sering dikenal dengan Covid-19.

\section{METODE PENELITIAN}

Pembuatan sistem informasi kehadiran dengan memanfaatkan E-KTP memerlukan metode pengembangan sistem yang digunakan juga sebagai framework atau kerangka kerja dalam penyusunan dan ujicoba. Metode penelitian dan pengembangan adalah metode penelitian yang digunakan untuk menghasilkan produk tertentu. Metode pengembangan sistem yang tepat untuk penelitian ini adalah metode pengembangan sistem yang berulang yang mampu mengevaluasi dan memonitoring sejauh mana sistem telah bekerja dengan baik dan apa saja yang perlu diperbaiki dalam penelitian ini []].

Metode pengembangan sistem yang dipakai dalam penelitian ini adalah metode pengembangan sistem Prototype yang merupakan metode pembuatan sistem yang prosesnya dibuat secara terstruktur dan berulang, dimana setiap tahap proses yang harus dilalui dengan cermat namun saat diakhiri dengan pengecekan untuk mengetahui apakah sebuah sistem sudah berjalan dengan baik atau belum. Jika dalam fase evaluasi tersebut terjadi kesalahan, maka sistem akan diperbaiki lagi dari langkah pertama dan akan berulang terus sampai sistem memenuhi syarat.

Metode pengembangan sistem prototype merupakan proses perulangan atau iterative yang melibatkan hubungan antar langkah atau tahapan kerja yang dekat antara perancang dan pengguna, sehingga sistem yang dihasilkan mampu menangani permasalahan yang langsung dihadapi oleh pengguna serta pembuat atau perancang mampu menyelesaikan permasalahan secara baik dan tepat. Prototyping mempunyai tujuan untuk menghasilkan sistem enterprise yang berkelanjutan dan dimulai dengan berinteraksi dengan pengguna untuk menggambarkan versi awal dari sistem tersebut [9].

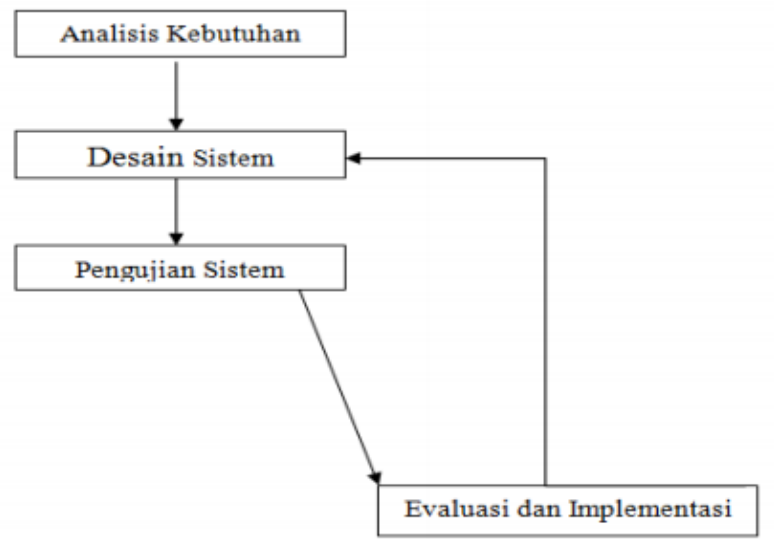

Gambar 1. Metode pengembangan sistem Prototype

Prototyping dimulai dengan pengumpulan kebutuhan, melibatkan pengembang dan pengguna sistem untuk menentukan tujuan, fungsi dan kebutuhan operasional sistem [10]. Langkah-langkah dalam prototyping yang diperlihatkan pada Gambar 1 sebagai berikut:

\subsection{Pengumpulan Kebutuhan.}

Pengumpulan kebutuhan adalah membuat pertemuan antar pengembang dengan pengguna untuk menentukan goals atau tujuan keseluruhan mengapa sistem informasi ini harus dibuat serta mengidentifikasi kebutuhan berupa garis besar kebutuhan dasar dari sistem yang akan dibuat. 


\subsection{Proses Desain}

Langkah berikutnya adalah membuat desain dari sistem yang akan dibuat yang dilandasi atas langkah sebelumnya yaitu pengumpulan kebutuhan sistem. Proses desain harus cepat dan tepat agar sistem dapat dibuat atau dibangun diatas pondasi kebutuhan sistem benar dan tepat.

\subsection{Membangun Prototipe.}

Setelah desain sudah disetujui pengguna, proses atau tahap selanjutnya adalah pembuatan sistem atau prototype sistem atas dasar desain pada tahap sebelumnya. Pembuatan prototype sistem ini juga harus benar dan tepat sesuai dengan kebutuhan dan permasalahan yang dihadapi oleh pengguna.

\subsection{Evaluasi}

Setelah pembuatan prototype selesai, dilakukanlan implementasi untuk mengetahui hasil dari desain sistem informasi yang akan diikuti dengan proses evaluasi dan perbaikan. Evaluasi dan pebaikan ini akan dilakukan sampai sistem sudah sesuai dengan harapan pengguna pada tahap $n$. Jika ada perbaikan maka akan diulangi dari langkah yang kedua yaitu proses mendesain sampai dengan langkah terakhir yaitu langkah ke empat, selalu berulang sampai dengan sistem ke $n$ sudah sesuai dengan harapan pengguna.

\section{HASIL DAN ANALISIS}

Penelitian ini dilakukan dengan protokol kesehatan pencegahan Covid 19 dengan mendatangi tujuan atau lokasi penelitian yang sudah ditentukan untuk mendapatkan informasi terkait sistem informasi kehadiran yang dibutuhkan oleh tempat penelitian, hal ini perlu dan mendesak dilakukan untuk mendapatkan informasi atau keadaan yang berlangsung ditempat penelitian.

\subsection{Analisis Kebutuhan}

Penelitian dimulai dengan melakukan analisa yang mendalam untuk mendapatkan informasi mengenai kebutuhan sistem yang akan dibangun dalam kaitannya mencegah penyebaran virus corona yang saat ini sedang terjadi. Setelah dilakukan pengumpulan data, dapat disimpulkan dalam beberapa poin yaitu :

1. Sistem kehadiran yang sekarang berjalan masih bersinggungan dengan orang lain atau masih memerlukan kontak dengan orang yang lain, hal itu menyebabkan potensi penyebaran virus yang cepat.

2. Diperlukan sebuah sistem informasi yang cara kerjanya tidak memerlukan kontak atau interaksi dengan petugas pencatat kehadiran sehingga meminimalisir penyebaran virus tersebut, dengan menggunakan E-KTP yang sudah dimiliki pegawai sebagai trigger atau media pencatatan dalam proses kehadiran.

3. Pencatatan kehadiran masih belum tersusun dengan baik, diperlukan manajemen kehadiran yang lebih baik.

4. Pelaporan kehadiran juga masih memerlukan waktu yang cukup banyak untuk merekap data kehadiran, diharapkan sistem mampu membuat laporan yang dapat cepat menyajikan data atau informasi kehadiran pegawai.

\subsection{Desain Sistem}

Setelah melakukan proses analisis kebutuhan maka selanjutnya adalah membuat atau menyusun desain sistem yang dapat memenuhi kebutuhan dari pengguna, desain tersebut terdiri dari penyusunan database, rancangan antarmuka dan pembuaan sistem informasi tersebut.

\subsubsection{Desain Fungsi Sistem}

1. Sistem pencatatan menggunakan RFID yang sudah terdapat dalam E-KTP

2. Sistem presensi dapat melakukan scan absensi masuk, absensi pulang dan tambah kartu id baru. 
3. Proses sistem presensi dilakukan berdasarkan waktu, bilamana pegawai tidak melakukan presensi sesuai waktu yang sudah ditentukan, maka pegawai tidak dapat melakukan presensi dan tidak terinput ke data presensi.

4. Sistem presensi terintegrasi dengan web server sehingga data masuk ke database secara otomatis dan cepat.

\subsubsection{Membangun Prototype}

Pembangunan prototype diawali dengan pembuatan use case diagram untuk mengetahui actor atau pihak siapa saja yang akan berkomunikasi dengan sistem, pembuatan use case akan mempermudah programmer dalam pembuatan sistem yang diperlukan oleh pengguna. Pemodelan yang penting dalam UML, untuk menjelaskan aspek fungsionalitas sistem dengan pemodelan use case. Use case dideskripsikan secara tekstual dalam bentuk use case scenario untuk menjelaskan interaksi yang terjadi antara actor dengan sistem. Selanjutnya, use case diilustrasikan secara visual dalam bentuk use case diagram untuk menggambarkan konteks dari sistem yang dikembangkan [11].

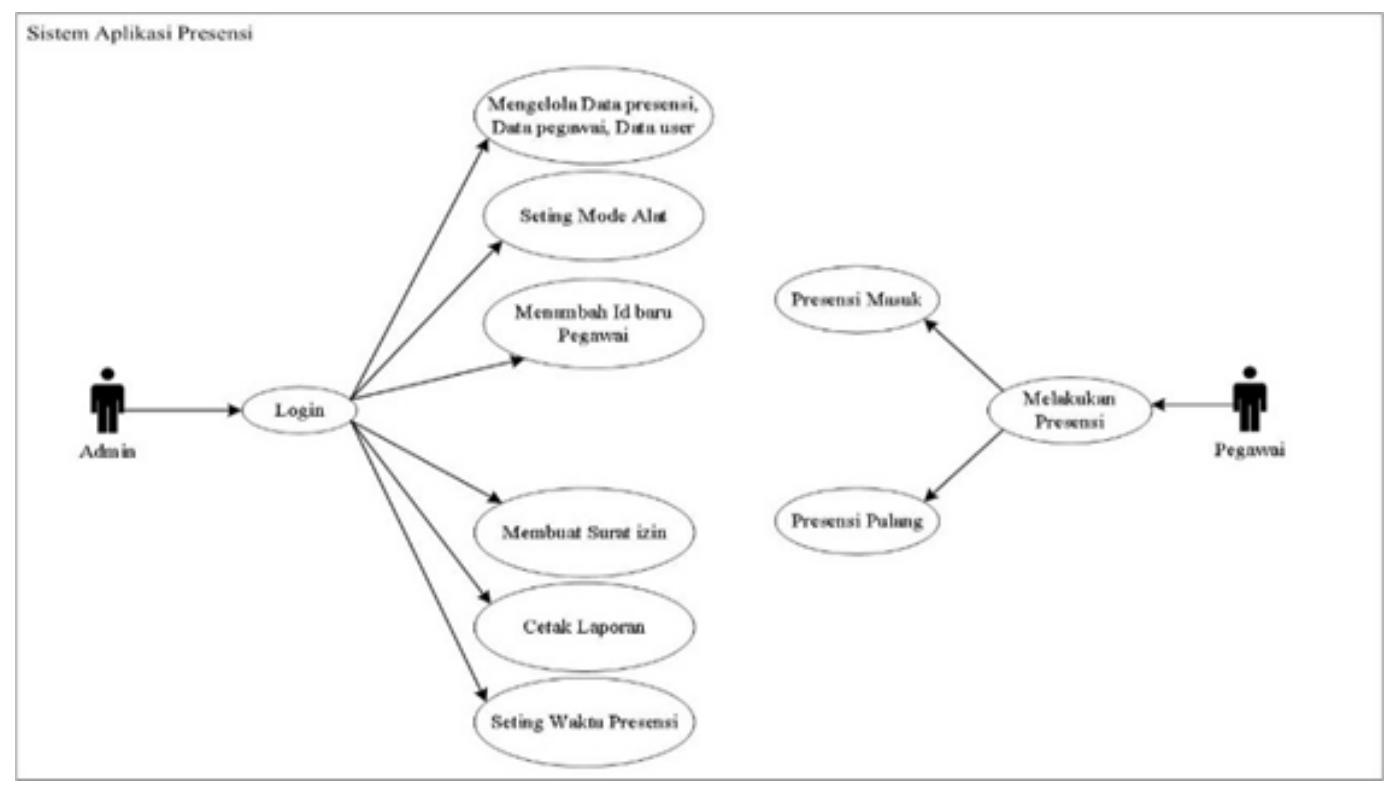

Gambar 2. Use case diagram sistem informasi kehadiran

Pada Gambar 2 dijelaskan bahwa admin dapat melakukan login untuk dapat mengelola aplikasi seperti data presensi, data pegawai, data user, menambah id baru, setting mode alat, membuat surat izin, mencetak laporan, dan setting. Sedangkan pegawai sebagai actor yang hanya dapat melakukan presensi kehadiran. Sedangkan pegawai sebagai pengguna yang menempelkan E-KTP kepada mesin untuk mencatat kehadiran datang dan pergi.

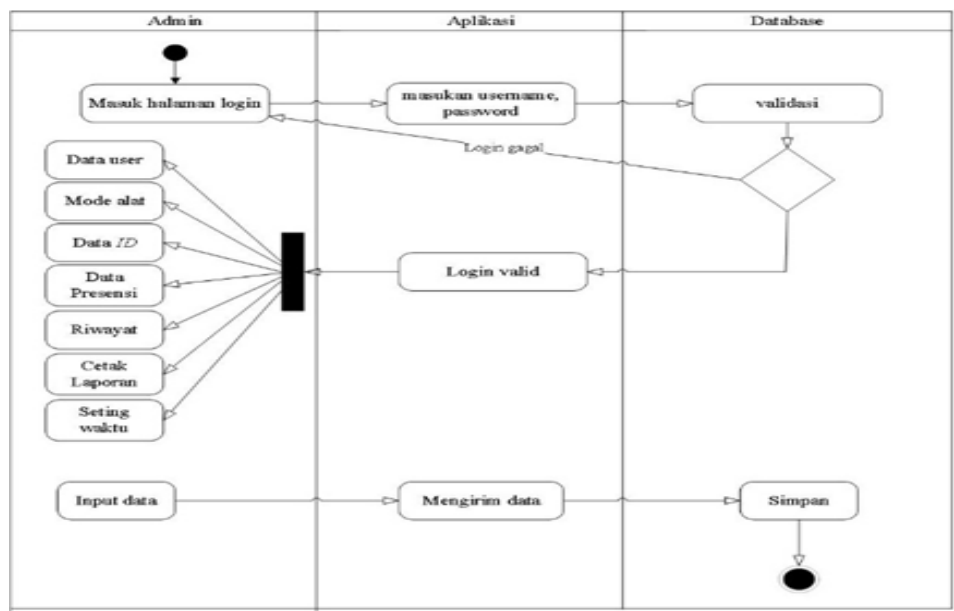

Gambar 3. Activity Diagram Administrator 
Berikutnya diperlukan sebuah diagam untuk menggambarkan aktivitas apa saja yang diperlukan di dalam sistem, terlihat pada Gambar 3, Activity Diagram menggambarkan workflow (aliran kerja) atau aktivitas dari sebuah sistem atau proses bisnis [12].Activity diagram menunjukan admin memerlukan login untuk dapat mengelola data user, mode alat, surat izin, data id, presensi, setting waktu dan cetak laporan. Selain itu juga diperlukan activity diagram untuk menu kehadiran, laporan dan proses pencatatan kehadiran. Dalam pembuatan prototype ini juga dibuat sequence diagram untuk mempermudah dalam pembuatan fitur atau fungsi dari sebuah sistem informasi yang dapat dilihat pada Gambar 4 dan Gambar 5.

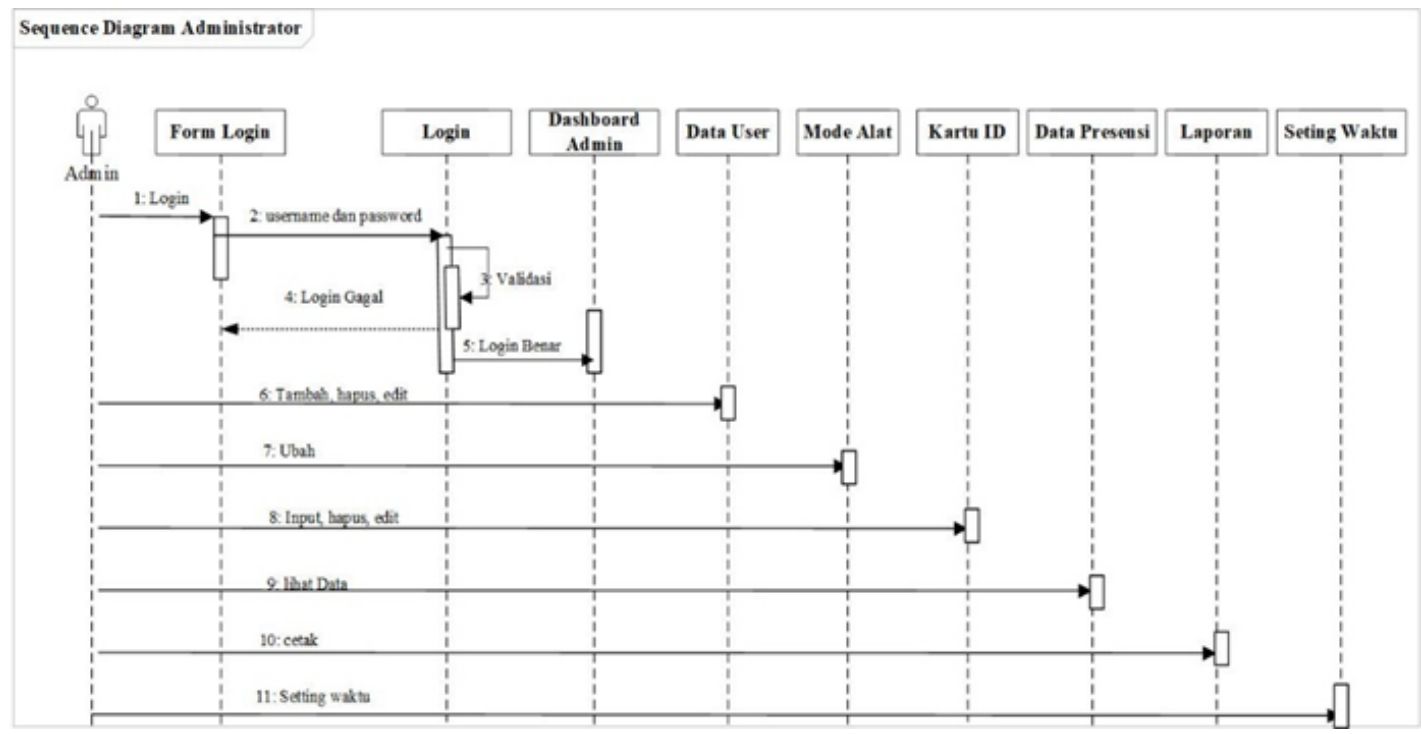

Gambar 4. Sequence Diagram Admin

Dalam Gambar 4 yaitu sequence diagram, admin dapat masuk ke halaman dashboard untuk login, dengan memasukan username dan password untuk divalidasi oleh sistem apakah username dan password benar. Jika benar maka admin dapat masuk ke halaman dashboard dan jika gagal akan kembali ke halaman login. Pada halaman dashboard admin dapat mengelola beberapa menu yaitu, menu user, mode alat, kartu id, data presensi laporan dan sebagainya.

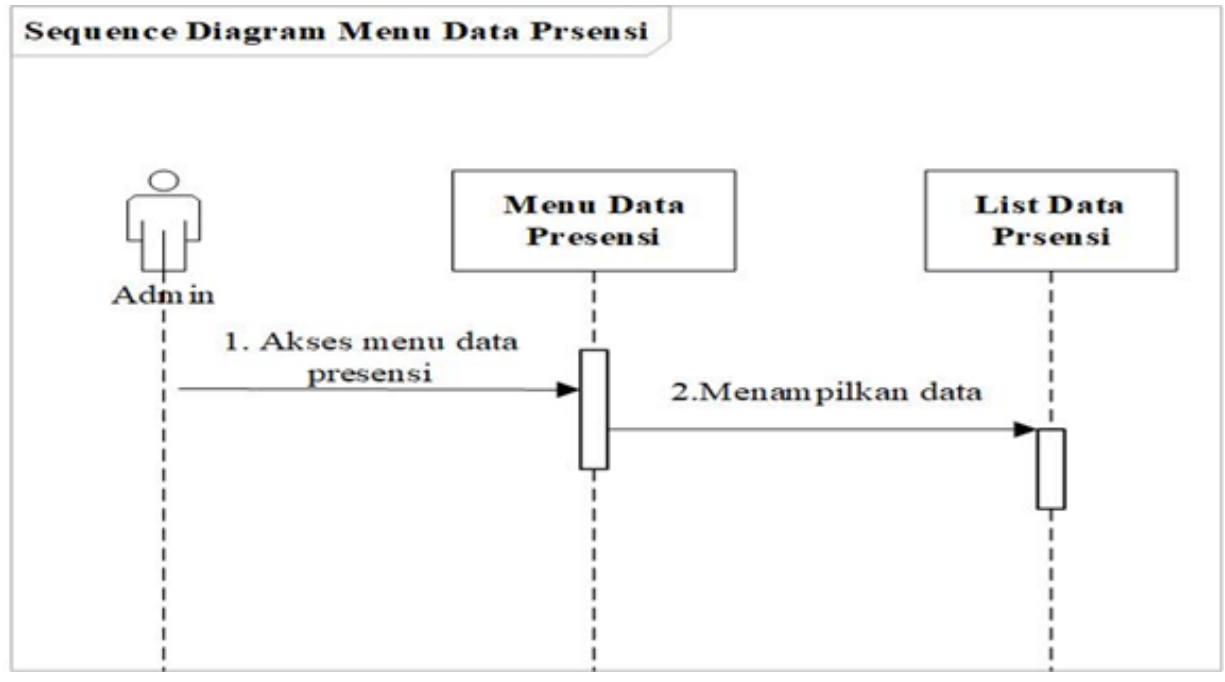

Gambar5. Sequence Diagram Presensi

Sedangkan pada Gambar 5 sequence diagarm proses presensi yang dimulai dari pegawai menempelkan kartu id pada alat presensi dan sistem akan membaca kartu tersebut. Setelah itu sistem mengirimkan data ke server, kemudian server menerima data dan akan melakukan pengolahan data serta pengecekan data, kemudian data yang telah diolah oleh server dan sistem atau alat presensi akan menampilkan notifikasi. 


\subsubsection{Perancangan Mikrokontroler}

Mikrokontroler adalah sebuah sistem komputer yang seluruh atau sebagian besar elemennya dikemas dalam satu chip IC, sehingga sering disebut single chip microcomputer [1]ㅡ.

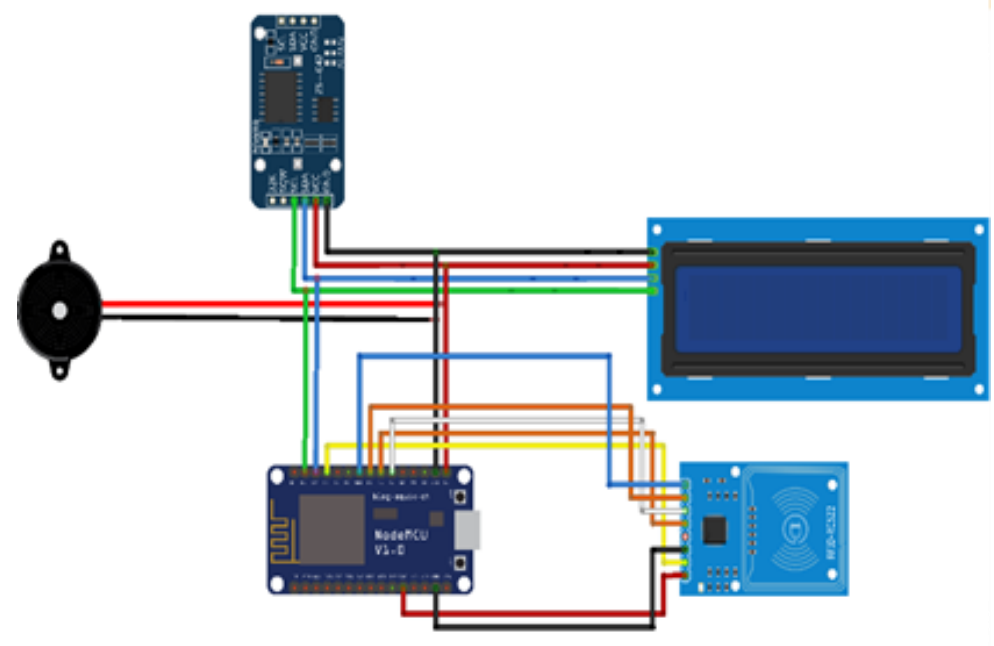

Gambar 6. Perancangan Mikrokontroler

Mikrokontroler digunakan sebagai alat untuk membaca E-KTP yang di dalamnya terdapat RFID yang merupakan sebagai pemicu dan pembawa data kehadiran, prinsip kerja dari sistem yang dirancang berdasarkan Gambar 6 adalah Node mсu eps8266 sebagai komponen utama sebagai input program untuk memberikan perintah pada komponen lainnya. Komponen RFID digunakan sebagai pembaca kartu id, yang kemudian dikirimkan ke web server lalu dicocokkan dengan data yang ada di database, setelah data berhasil dicocokkan maka tampil notifikasi informasi pada layer LCD (Liquid Crystal Display) dan diikuti dengan bunyi buzzer.

\subsubsection{Pembuatan Sistem Informasi Kehadiran}

Tahap selanjutnya adalah proses pembuatan sistem informasi kehadiran yang di dalamnya terdapat fitur atau fungsi:

1. Data user, digunakan untuk menyimpan data admin atau orang yang dapat mengelola sistem.

2. Data pegawai, digunakan untuk menyimpan data diri pegawai.

3. Data presensi, digunakan untuk menyimpan data presensi yang terdiri dari presensi masuk dan pulang setiap hari.

4. Data riwayat, digunakan untuk menampilkan keseluruhan data presensi yang ada di database.

5. Data surat izin, digunakan untuk membuat dan menyimpan data surat keterangan izin pegawai.

6. Data laporan, digunakan untuk membuat laporan harian.

7. Data konfigurasi alat, digunakan untuk mengubah data alat menjadi mode presensi atau mode tambah kartu Id pegawai.

8. Data setting waktu, digunakan untuk mengubah waktu yang akan ditentukan.

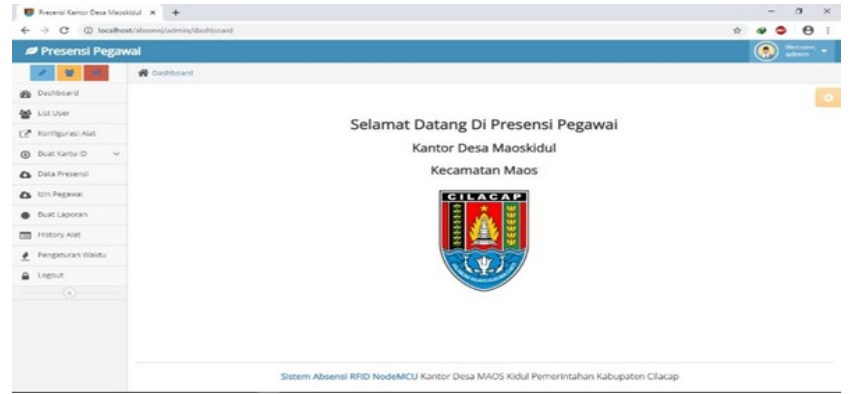

Gambar 7. Menu utama 
Gambar 7 merupakan halaman utama yang dipakai oleh petugas atau oleh user untuk mengoperasikan sistem informasi kehadiran ini, terdapat beberapa menu yang dapat diakses oleh seorang user atau admin, yaitu menu list user, konfigurasi alat, data kartu id, data presensi, izin pegawai, cetak laporan, dan pengaturan waktu. Halaman utama merupakan halaman yang diatur sebagai tampilan pertama saat sistem informasi ini diakses oleh administrator atau petugas pencatat kehadiran, melalui halaman ini fitur-fitur atau fungsi utama yang ada dalam sistem informasi dapat diakses dan digunakan.

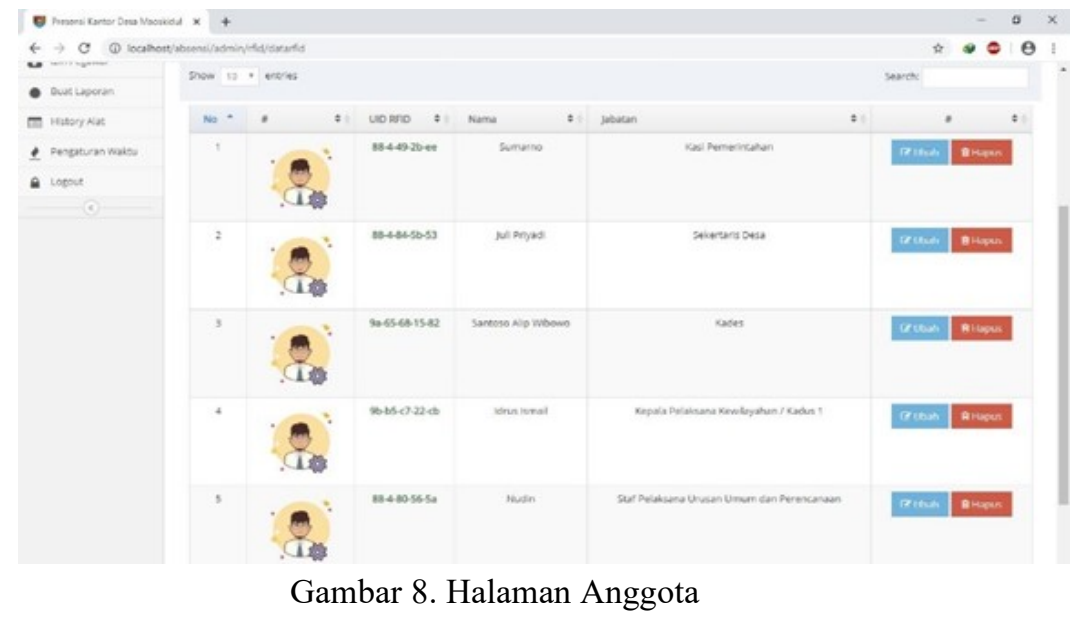

Halaman anggota yang ditampilkan pada gambar 8 merupakan halaman untuk mengatur data karyawan atau pegawai, yang didalamnya terdapat daftar pegawai yang sudah direkam atau disimpan data chip dari EKTP sehingga siap digunakan untuk mencata system informasi. Melalui halaman ini juga admin dapat mencetak daftar petugas dan juga dapat untuk menyimpan data pegawai baru untuk, admin juga dapat mengubah data melalui halaman ini.

Sistem kehadiran telah dibuat dan memiliki fitur yang sesuai dengan kebutuhan pengguna dan sesuai dengan analisa fungsi yang telah dilakukan, fungsi yang sudah dibuat akan dicek dan dicoba oleh tester internal (pengujian alpha) untuk mengetahui bagian mana yang masih terdapat kesalahan atau perlu adanya perbaikan. Sistem informasi ini juga didukung dengan alat pembaca E-KTP yang di dalamnya terdapat RFID, alat ini akan menterjemahkan chip RFID menjadi sebuah bilangan atau karakter untuk ditransfer kepada sistem yang akan mencatat kedatangan atau waktu pulang seorang pegawai.

\subsection{Pengujian Sistem}

Setelah dilakukan pembuatan sistem, langkah selanjutnya adalah pengujian yang akan dilakukan oleh pihak internal pengembang sistem informasi atau yang sering dikenal sebagai pengujian alpha. Pembuatan suatu perangkat lunak yang berkualitas selalu memperhatikan kebutuhanakan penggunanya, sehingga mampu memberikan solusi dari permasalahan yang dihadapi oleh parapenggunanya. Selain itu, suatu aplikasi yang berkualitas selalu melalui tahapan-tahapan pengujian yang tidak singkat sehingga benar-benar menjamin akan kualitas produknya [14].

Pengujian ini bertujuan untuk mengetahui kinerja code pemrograman apakah sudah berjalan dengan baik dan benar untuk menunjang kecepatan dan ketepatan data, serta menguji apakah seri-seri atau jenis-jenis EKTP yang dimiliki para pegawai mampudi baca atau diterjemahkan dengan baik. Pengujian dilakukan dengan dua sisi yaitu dari sudut pandang pengguna dan sudut pandang programmer, hasil dari pengujian programmer query masih perlu diperbaiki dengan pengunaan function untuk beberapa fitur penyediaan informasi yang banyak misalnya penyajian informasi rekapitulas kehadiran. Sedangkan dari sudut pandang pengguna, sistem informasi kehadiran sudah sesuai dengan harapan dan sesuai dengan kebutuhan pengguna.

\subsection{Implementasi dan Evaluasi}

Keberhasilan implementasi Sistem teknologi Informasi dipengaruhi oleh berbagai faktor yang komplek. Sedangkan kegagalan implementasi sistem teknologi informasi, biasanya terjadi karena tidak kompatibelnya sistem teknologi informasi dengan proses bisnis dan informasi yang diperlukan organisasi [15]. Proses implementasi yang dilakukan adalah mengatur satu computer yang digunakan sebagai computer penyedia data atau pelayan data dan satu komputer sebagai pencatat RFID yang terekam, sedangkan alat pembaca RFID yang dibuat diletakkan dalam meja yang telah disediakan. Dalam implementasi sistem cukup terkendala dengan ruangan yang sempit sehingga diperlukan alat pembaca RFID yang diletakan diluar ruangan untuk pencegahan 
antrian yang banyak. Evaluasi yang diberikan oleh pihak tempat penelitian adalah pembacaan alat yang kurang cepat, sehingga pengembang memerlukan upgrading atau meningkatkan mesin pembaca RFID yaitu dengan cara mengganti sensor pembacaan RFID menjadi sensor yang cepat memberikan respon.

Sedangkan pengujian penambahan kartu baru berhasil dengan menampilkan id kartu dengan notifikasi 'berhasil tambah kartu' pada layar LCD dan ter-input ke web server, pengujian presensi masuk dan presensi pulang berhasil terbaca berdasarkan waktu (telat masuk, sudah absen masuk/pulang), sampai dengan pengujian jarak baca sensor RFID, dimana jarak baca kartu hanya dapat terbaca dalam jarak nol sampai tiga $(0-3) \mathrm{cm}$. Begitu pun pada pengujian aplikasi website dimulai dari login, memasukan data pegawai, mengubah mode presensi, menampilkan data kartu id dan data presensi pegawai sampai dengan cetak laporan.

\section{KESIMPULAN}

Berdasarkan pengujian dapat disimpulkan bahwa RFID tag dapat terbaca oleh RFID reader dan RFID reader bisa membaca input dari RFID tag ketika RFID tag posisinya berada nol sampai tiga (0-3) $\mathrm{cm}$ dari $R F I D$ reader. Sistem pembaca kartu RFID dapat bekerja dengan baik, dimana RFID Reader dapat membaca ID pada kartu dan dapat ditampilkan pada aplikasi webserver. Berdasarkan pengujian ketika melakukan scan tag atau kartu id ke RFID reader maka akan tampil notifikasi pada layar LCD dan bersamaan dengan bunyi buzzer. Mampu menghasilkan data kehadiran yang lebih akurat dan lebih terkontrol dibandingkan sistem absensi yang digunakan sebelumnya.Keuntungan yang diperoleh dari pemanfaatan RFID sangat membantu pada proses identifikasi absensi kehadiran pegawai dengan ID yang berbeda-beda, sehingga tidak ada kecurangan absensi. Serta mengurangi potensi penyebaran virus yang sedang dihadapi dimasa pandemik ini, karena mengurangi kontak dengan manusia yang lain.

\section{UCAPAN TERIMA KASIH}

Ucapan terima kasih kami sampaikan kepada pihak yang telah mendukung dan berperan dalam penelitian ini, terutama untuk Lembaga Penelitian dan Pengabdian Kepada Masyarakat (LPPM) Universitas Amikom Purwokerto yang telah membiayai penelitian ini di tahun 2020 serta lokasi atau tempat penelitian yang telah mengijinkan kami dalam melakukan penelitian ini.

\section{REFERENSI}

[1] N. Mona, "Konsep Isolasi Dalam Jaringan Sosial Untuk Meminimalisasi Efek Contagious ( Kasus Penyebaran Virus Corona Di Indonesia)," Jurnal Sosial Humaniora Terapan, vol. 2, no. 2, pp. 117$125,2020$.

[2] N. R. Yunus and A. Rezki, "Kebijakan Pemberlakuan Lock Down Sebagai Antisipasi Penyebaran Corona Virus Covid-19," Jurnal Sosial dan Budaya Syar-i, vol. 7, no. 3, pp. 227-238, 2020.

[3] N. D. Suryani, S. T. Rahayu, and U. Ardiningsih, "Optimalisasi Teknologi Biometrics dalam Program E-KTP dengan Penambahan Data Struktur Gigi D dan Kartu Sakti Sebagai Alternatif Satu Kartu Multifungsi," Jurnal Ilmiah Mahasiswa Fakultas Kesehatan Masyarakat Universitas Diponegoro, vol. 4, no. 1, pp. 18-25, 2014.

[4] M. P. Febriharini, "Pelaksanaan Program E-KTP dalam Rangka Tertib Administrasi Kependudukan," Serat Acitya, vol. 5, no. 2, pp. 17-30, 2016.

[5] A. Ridwan, Darjat, and Sudjadi, "Pemanfaatan Teknologi RFID Melalui Kartu Identitas Dosen Pada Prototipe Sistem Ruang Kelas Cerdas,” vol. 6, no. 2, pp. 62-68, 2014.

[6] W. Zendrato, "Gerakan Mencegah Daripada Mengobati Terhadap Pandemi Covid-19," Jurnal Education and development, vol. 8, no. 2, pp. 242-248, 2020.

[7] W. Nugraha and M. Syarif, "Penerapan Metode Prototype dalam Perancangan Sistem Informasi Penghitungan Volume dan Cost Penjualan Minuman Berbasis Website," Jurnal Sistem Informasi Musirawas, vol. 3, no. 2, pp. 94-101, 2018.

[8] S. Sugiyono, Metode Penelitian Kuantitatif, Kualitatif, dan R\&D. Bandung: Alfabeta, 2009.

[9] D. Purnomo, "Model Prototyping Pada Pengembangan Sistem Informasi," Jurnal Informatika Merdeka Pasuruan, vol. 2, no. 2, pp. 54-61, 2017.

[10] P. M. Ogedebe and B. P. Jacob, "Software Prototyping: A Strategy to use When user Lacks Data Processing Experience," ARPN Journal of Systems and Software, vol. 2, no. 6, 2012.

[11] T. A. Kurniawan, "Pemodelan Use Case (UML): Evaluasi Terhadap beberapa Kesalahan dalam Praktik," Jurnal Teknologi Informasi dan Ilmu Komputer, vol. 5, no. 1, p. 77, 2018.

[12] A. Hendini, "Pemodelan Uml Sistem Informasi Monitoring Penjualan dan Stok Barang," Jurnal Khatulistiwa Informatika, vol. 2, no. 9, pp. 107-116, 2016.

[13] A. Nur Nazilah Chamim, "Penggunaan Microcontroller Sebagai Pendeteksi Posisi dengan Menggunakan Sinyal GSM,” Jurnal Informatika, vol. 4, no. 1, pp. 430-439, 2010.

[14] H. T. Hidayat, "Pengujian Kualitas Kelayakan Perangkat Lunak dengan Penerapan Perancangan Model 
Rapid Application Development," Electronics, Informatics, and Vocational Education, vol. 2, no. 2 , pp. 121-129, 2017.

[15] D. Krisbiantoro, M. Suyanto, and E. Taufiqluthfi, "Evaluasi Keberhasilan Implementasi Sistem Informasi dengan Pendekatan HOT FIT Model (Studi Kasus: Perpustakaan STMIK AMIKOM Purwokerto)," pp. 9-10, 2015. 